Seong Hwan Park, ${ }^{1,2}$ Ph.D., M.D.; Yong Zhang, ${ }^{2}$ Ph.D., M.D.; Huguo Piao, ${ }^{2}$ M.D.; Dong Ha Yu, ${ }^{2}$ B.S.; Hyun Ju Jeong, ${ }^{2}$ B.S.; Ga Young Yoo, ${ }^{2}$ B.S.; Tae-Ho Jo, ${ }^{3}$ Ph.D.; and Juck-Joon Hwang, ${ }^{2}$ Ph.D., M.D.

\title{
Sequences of the Cytochrome C Oxidase Subunit I (COI) Gene are Suitable for Species Identification of Korean Calliphorinae Flies of Forensic Importance (Diptera: Calliphoridae)
}

\begin{abstract}
Calliphorinae fly species are important indicators of the postmortem interval especially during early spring and late fall in Korea Although nucleotide sequences of various Calliphorinae fly species are available, there has been no research on the cytochrome c oxidase subunit I (COI) nucleotide sequences of Korean Calliphorinae flies. Here, we report the full-length sequences of the COI gene of four Calliphorinae fly species collected in Korea (five individuals of Calliphora vicina, five Calliphora lata, four Triceratopyga calliphoroides and three Aldrichina grahami). Each COI gene was amplified by polymerase chain reaction and directly sequenced and the resulting nucleotide sequences were aligned and analyzed by MEGA4 software. The results indicate that COI nucleotide sequences can be used to distinguish between these four species. Our phylogenetic result coincides with recent taxonomic views on the subfamily Calliphorinae in that the genera Aldrichina and Triceratopyga are nested within the genus Calliphora.
\end{abstract}

KEYWORDS: forensic science, forensic entomology, postmortem interval, Calliphorinae, Calliphoridae, Diptera, cytochrome c oxidase subunit I, species identification

Identification of fly species is essential in forensic entomology, which provides valuable knowledge for estimating the postmortem interval (PMI) (1). A lack of identification keys for immature stages limits the utilization of conventional morphological identification methods. Therefore, many authors have proposed DNAbased identification methods, especially using the cytochrome $\mathrm{c}$ oxidase subunit I (COI) gene (2-6). The earliest visitors to a corpse are usually flies, especially those in the family Calliphoridae (7), which mostly belong to one of three subfamilies: Calliphorinae, Luciliinae, and Chrysomynae. Subfamily Calliphorinae consists of several genera such as Calliphora, Aldrichina, Triceratopyga, Eucalliphora, and Onesia. Calliphorinae flies in Japan inhabit relatively cooler climates than other Calliphoridae flies do (8-10), which is also confirmed by our observation of Korean Calliphorinae flies (not published). Calliphorinae flies are important indicators of PMI especially during the early spring or late fall in Korea, when flies in the subfamily Luciliinae are not active. Although Calliphorinae flies share many biological characteristics, the duration of immature stages differs considerably among Calliphorinae species (10-13). Therefore, inaccurate species identification may cause errors in estimating PMI. Although many DNA sequences of Calliphorinae species from various geographic regions have been analyzed previously, COI sequences of the Calliphorinae flies in Korea have not yet been reported. Here, we report the full-length sequences (1539 nucleotides) of the COI gene of four forensically

${ }^{1}$ Department of Ecology and Evolutionary Biology, University of Michigan, Ann Arbor, MI, U.S.A.

${ }^{2}$ Department of Legal Medicine, College of Medicine, Korea University, Seoul, Korea.

${ }^{3}$ Department of Science Education, Chinju National University of Education, Jinju, Korea.

Received 3 Mar. 2008; and in revised form 8 Oct. 2008; accepted 25 Oct. 2008. important Calliphorinae species: Calliphora vicina, Calliphora lata, Triceratopyga calliphoroides, and Aldrichina grahami collected in Korea. To our knowledge, this is the first report of the COI sequence of $T$. calliphoroides and the full sequences of COI genes of C. lata and A. grahami.

\section{Materials and Methods}

\section{Fly Collection and Species}

Adult flies were collected from various regions of South Korea using baits such as pork liver or raw squid. Morphological identification was done under a dissecting microscope by an expert dipterologist with strict criteria (8). Five $C$. vicina, five $C$. lata, four T. calliphoroides, and three A. grahami were examined in this study (Table 1).

\section{DNA Extraction}

Whole bodies, except compound eyes, were dried at $55^{\circ} \mathrm{C}$, and ground to powder. DNA was extracted using the conventional phenol/chloroform/isoamylalcohol method (14).

\section{Primer Design}

After aligning mitochondrial sequences of Chrysomya putoria (NCBI accession number NC002697), Cochliomyia hominivorax (NC002660), and Haematobia irritans (NC007102), upstream and downstream primers were selected from the tRNA-cysteine and the cytochrome c oxidase subunit I regions, respectively. Several internal primers were selected or modified from published articles for some samples that failed to produce visible DNA bands with the 
TABLE 1-COI sequences used in this study.

\begin{tabular}{|c|c|c|c|c|}
\hline GenBank Accession Number & Species Name & Coverage (length) & Location & Reference \\
\hline EU880176-EU880179 & Triceratopyga calliphoroides & $1-1,539(1,539)$ & South Korea & Newly sequenced \\
\hline EU880180-EU880182 & Aldrichina grahami & $1-1,539(1,539)$ & South Korea & Newly sequenced \\
\hline EU880183-EU880187 & Calliphora lata & $1-1,539(1,539)$ & South Korea & Newly sequenced \\
\hline EU880188-EU880192 & Calliphora vicina & $1-1,539(1,539)$ & South Korea & Newly sequenced \\
\hline AY818124 & Aldrichina grahami & $1,068-1,345(278)$ & Western China & Cai et al. (unpublished) \\
\hline DQ328667 & Aldrichina grahami & $1,001-1,348(348)$ & China & Yin et al. (unpublished) \\
\hline DQ345097 & Aldrichina grahami & $220-1,533(1,314)$ & China & Zhu et al. (unpublished) \\
\hline DQ345074 & Calliphora augur & $220-1,533(1,314)$ & China & Zhu et al. (unpublished) \\
\hline AF259505 & Cynomya cadaverina & $1-1,539(1,539)$ & U.S.A. & Wells (21) \\
\hline $\mathrm{N} / \mathrm{A}^{*}$ & Calliphora lata & $1,023-1,326(304)$ & Japan & Saigusa et al. (9) \\
\hline DQ345093 & Calliphora loewi & $220-1,533(1,314)$ & China & Zhu et al. (unpublished) \\
\hline DQ345094 & Calliphora nigribarbis & $220-1,533(1,314)$ & China & Zhu et al. (unpublished) \\
\hline DQ345095 & Calliphora pattoni & $220-1,533(1,314)$ & China & Zhu et al. (unpublished) \\
\hline AJ417702 & Calliphora vicina & $1-1,539(1,539)$ & U Bristol colony, U.K. & Stevens et al. (22) \\
\hline AY842603 & Calliphora vicina & $719-1,536(815)$ & Australia & Wallman et al. (23) \\
\hline AY842604 & Calliphora vicina & $716-1,532(815)$ & Australia & Wallman et al. (23) \\
\hline DQ345096 & Calliphora vicina & $220-1,533(1,314)$ & China & Zhu et al. (unpublished) \\
\hline AF295557 & Eucalliphora latifrons & $1-1,533(1,533)$ & Canada & Wells and Sperling (24) \\
\hline L14945 & Lucilia illustris & $1-1,539(1,539)$ & $\mathrm{N} / \mathrm{A}^{*}$ & Sperling et al. (2) \\
\hline
\end{tabular}

*N/A stands for "not available."

initial primer set $(9,15,16)$. Primer sequences used in this study are listed in Table 2.

\section{Polymerase Chain Reaction and Sequencing}

Polymerase chain reaction (PCR) was performed with $2.5 \mu \mathrm{L}$ $10 \times$ Gold Buffer (Applied Biosystems, Foster City, CA), 6.25 nmole $\mathrm{MgCl}_{2}, 5$ nmole (each) dNTP mix, 5 pmole primers and $0.5 \mathrm{U}$ AmpliTaq Gold DNA polymerase (Applied Biosystems) in the $25 \mu \mathrm{L}$ reaction volume. The thermal cycle conditions were 1 cycle at $95^{\circ} \mathrm{C}$ for $11 \mathrm{~min}, 35$ cycles at $95^{\circ} \mathrm{C}$ for $30 \mathrm{sec}, 55^{\circ} \mathrm{C}$ for $30 \mathrm{sec}$, and $72^{\circ} \mathrm{C}$ for $90 \mathrm{sec}$, and $72^{\circ} \mathrm{C}$ for $15 \mathrm{~min}$ of final extension with GeneAmp 2720 or 9600 PCR Systems (Applied Biosystems). The annealing temperatures were optimized for each reaction. After PCR, remaining $\mathrm{dNTPs}$ and primers in PCR

TABLE 2-Primer sequences.

\begin{tabular}{lll}
\hline $\begin{array}{l}\text { Primer } \\
\text { Names }\end{array}$ & \multicolumn{1}{c}{ Sequences } & \multicolumn{1}{c}{ Binding Locations } \\
\hline F1 & CCTTTAGAATTGCAGTCTAATGTCA & tRNA-Cysteine \\
F2 & GGAGGATTTGGAAATTGATTAGTTCC & $220-245$ on COI \\
F3 & CAACATTTATTTTGATTCTTTGG & $688-710$ on COI \\
F4 & CTGCTACTTTATGAGCTTTAGG & $1000-1022$ on COI \\
R1 & CCTAAATTTGCTCATGTTGACA & $2-23$ on COII \\
R2 & CAAGTTGTGTAAGCATC & $1327-1343$ on COI \\
R3 & CCAAAGAATCAAAATAAATGTTG & $688-710$ on COI \\
\hline
\end{tabular}

products were inactivated by $10 \mathrm{U}$ calf intestinal phosphatase and $10 \mathrm{U}$ exonuclease I (New England BioLabs Inc., Ipswich, MA). DNA sequencing reactions were performed with the BigDye Terminator v1.1 or v3.1 (Applied Biosystems). DNA sequences were analyzed mainly on an ABI PRISM 3730xl genetic analyzer or partly on an ABI PRISM 310 genetic analyzer.

\section{Phylogenetic Analysis}

Phylogenetic analysis was performed using MEGA4 software (17). Newly determined nucleotide sequences were compared with previously reported sequences in NCBI GenBank or literatures (Table 1). The phylogenetic tree was generated by neighbor-joining method with a p-distance model and 1000 replicates of bootstrapping. Gaps were considered as "complete deletion." Sequences shorter than $1.3 \mathrm{~kb}$ were excluded from the phylogenetic analysis to avoid decrease of number of sites. Shorter sequences were compared by pairwise percent distances. Percent distances were also calculated by MEGA4 software.

\section{Results and Discussion}

We analyzed the full-length sequences of COI genes of four Calliphorinae species from three genera. The intraspecific sequence distances range from 0.0 to $0.4 \%$ whereas interspecific distances range from 3.8 to $6.4 \%$ (Table 3 ), which indicates that species-level identification is possible with these sequences. Next, the percent distances were calculated between our data and previously reported

TABLE 3-Percent distance matrix of four Korean Calliphorinae fly species: Calliphora lata (EU880183-EU880187), Calliphora vicina (EU880188EU880192), Tricertopyga calliphoroides (EU880176-EU880179), and Aldrichina grahami (EU880180-EU880182).

\begin{tabular}{lcccc}
\hline & C. lata & C. vicina & T. calliphoroides & A. grahami \\
\hline C. lata & $0.0-0.1$ & & & \\
C. vicina & $3.8-4.0$ & $0.0-0.3$ & & \\
T. calliphoroides & $4.7-5.0$ & $3.8-4.1$ & $0.1-0.6$ & $6.2-6.5$ \\
A. grahami & $6.0-6.2$ & $5.8-6.0$ & $8.2-8.4$ & $0.0-0.1$ \\
L. illustris* & $7.2-7.3$ & $7.3-7.5$ & $8.7-8.8$ & -8 \\
\hline
\end{tabular}

*Lucilia illustris (L14945) is included as outgroup. 
sequences. Four previously reported $C$. vicina sequences (NCBI accession numbers AY842603, AY842604, DQ345096, and AJ417702) showed only $0.2-0.6 \%$ distances from our data. Although no $C$. lata sequences are available in NCBI GenBank yet, there is a COI sequence reported as Calliphora nigribarbis $(C$. nigribarbis DQ345094), a synonym for $C$. lata (18) and a short sequence (304 nucleotides) of Japanese $C$. lata reported only in print by Saigusa et al. (9). DQ345094 and the Japanese C. lata sequence showed $0.2 \%$ and $0.7 \%$ to $1.0 \%$ distances from our $C$. lata sequences, respectively. Among three Chinese A. grahami sequences in NCBI GenBank (DQ345097, DQ328667, and AY818124), DQ345097 and DQ328667, both submitted by Zhu et al., were closely related to our data $(0.1-0.6 \%)$. However, AY818124 diverged considerably from ours and also from two other Chinese sequences at $6.5-6.9 \%$ distances, while showing a striking similarity to $C$. vicina sequences $(0.7-1.4 \%$ sequence distances). Therefore, a possibility of misidentification should be considered for AY818124. Because there are no previously reported nucleotide sequences of $T$. calliphoroides, we performed a BLAST search with our $T$. calliphoroides sequences and found that our sequences showed no more than $96 \%$ similarity with any entries in the NCBI GenBank.

The phylogenetic tree, generated from our data and previously reported sequences of Calliphorinae species, revealed a paraphyly of the genus Calliphora (Fig. 1). A. grahami, Eucalliphora latifrons (E. latifrons AF295557), T. calliphoroides, and Cynomya cadaverina (C. cadaverina AF259505) occupied positions scattered among

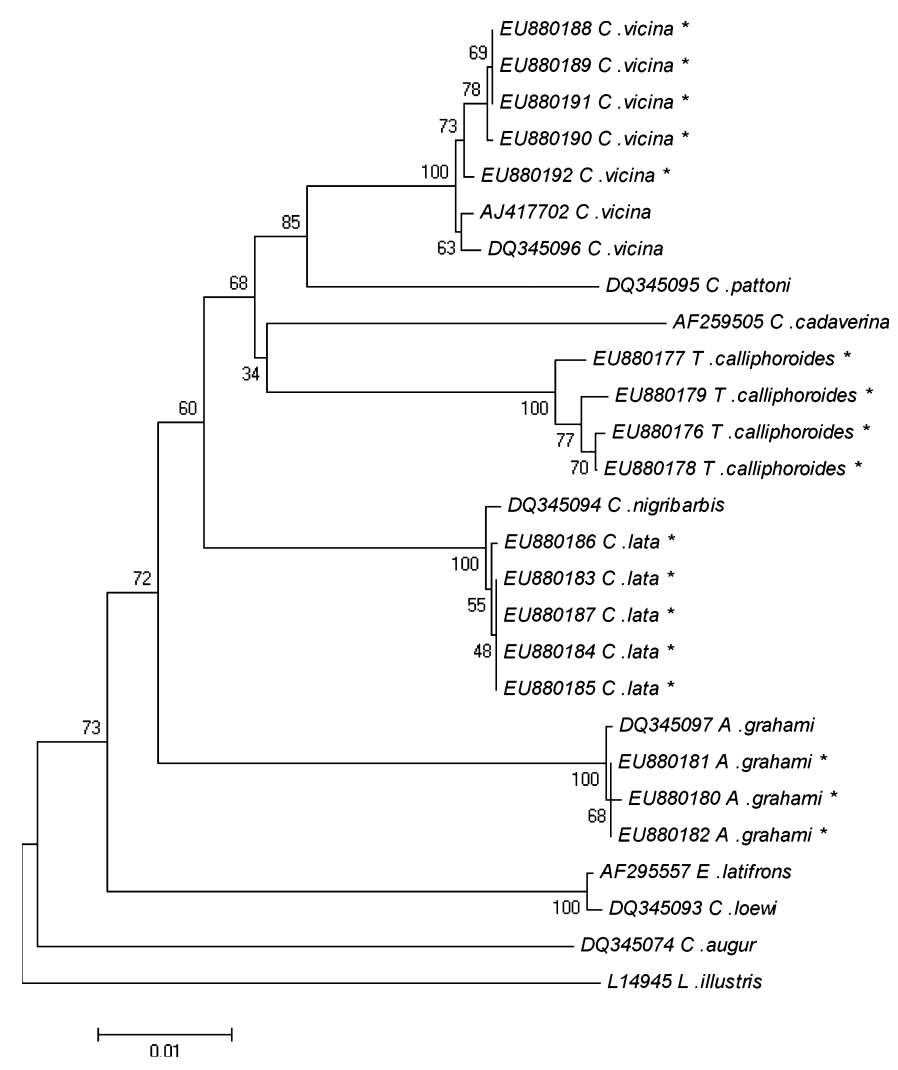

FIG. 1-Neighbor-joining phylogenetic tree of the COI sequences of Korean Calliphorinae flies combined with previously reported data. Samples marked with "*” are from this study. Numbers on the branches are percent values from 1,000 bootstrap replicates. Lucilia illustris (L14945) is included as outgroup. the species in the genus Calliphora. This phylogenetic result coincides with taxonomic views on the genera Aldrichina and Eucalliphora by Rognes (19) and Whitworth (20), which consider genera Aldrichina and Eucalliphora as synonymies for the genus Callipho$r a$. Our result suggests that the genus Triceratopyga may also be a synonymy for the genus Calliphora.

In conclusion, our results demonstrate that COI nucleotide sequence analysis is suitable for species identification of Korean Calliphorinae flies. Furthermore, our result can be a reference for the future taxonomic revision in the subfamily Calliphorinae.

\section{Acknowledgments}

We wish to thank Dr. Soochin Cho of the University of Michigan for phylogenetic advice. We also appreciate Dr. Andy Z. Lehrer for the taxonomic information about Calliphora lata and Calliphora nigribarbis. This study was partially supported by a grant to J-J. Hwang from Glami Co., Ltd., Seoul, Korea.

\section{References}

1. Amendt J, Campobasso CP, Gaudry E, Reiter C, LeBlanc HN, Hall MJ. Best practice in forensic entomology-standards and guidelines. Int $\mathrm{J}$ Legal Med 2007;121(2):90-104.

2. Sperling FA, Anderson GS, Hickey DA. A DNA-based approach to the identification of insect species used for postmortem interval estimation. J Forensic Sci 1994;39(2):418-27.

3. Malgorn Y, Coquoz R. DNA typing for identification of some species of Calliphoridae. An interest in forensic entomology. Forensic Sci Int 1999;102(2-3):111-9.

4. Bernasconi MV, Pawlowski J, Valsangiacomo C, Piffaretti JC, Ward PI. Phylogeny of the scathophagidae (Diptera, calyptratae) based on mitochondrial DNA sequences. Mol Phylogenet Evol 2000;16(2):308-15.

5. Wells JD, Sperling FA. A DNA-based approach to the identification of insect species used for postmortem interval estimation and partial sequencing of the cytochrome oxidase b subunit gene I: a tool for the identification of European species of blow flies for postmortem interval estimation. J Forensic Sci 2000;45(6):1358-9.

6. Wallman JF, Donnellan SC. The utility of mitochondrial DNA sequences for the identification of forensically important blowflies (Diptera: Calliphoridae) in southeastern Australia. Forensic Sci Int 2001; 120(1-2):60-7.

7. Amendt J, Krettek R, Zehner R. Forensic entomology. Naturwissenschaften 2004;91(2):51-65.

8. Kano R, Shinonaga S. Calliphoridae (Insecta: Diptera), 1st edn. Tokyo: Biological [i.e. Biogeographical] Society of Japan, 1968.

9. Saigusa K, Takamiya M, Aoki Y. Species identification of the forensically important flies in Iwate prefecture, Japan based on mitochondrial cytochrome oxidase gene subunit I (COI) sequences. Leg Med (Tokyo) 2005;7(3): 175-8.

10. Nishida K. Hae yotsyuno hatsuikusokudokara hitono shigokeikanissuno suiteini kansuru zikkenteki kisokenkyu (Experimental studies on the estimation of postmortem intervals by means of fly larvae infesting human cadavers). Nihon Hoigaku Zasshi 1984;38(1):24-41.

11. Kamal AS. Comparative study of thirteen species of Sarcosaprophagous Calliphoridae and Sarcophagidae (Diptera) I. Bionomics. Ann Entomol Soc Am 1958;51:261-71.

12. Marchenko MI. Medicolegal relevance of cadaver entomofauna for the determination of the time of death. Forensic Sci Int 2001;120(1-2):89109.

13. Anderson GS. Minimum and maximum development rates of some forensically important Calliphoridae (Diptera). J Forensic Sci 2000; 45(4):824-32.

14. Butler JM. Forensic DNA typing: biology, technology, and genetics of STR markers, 2nd ed. Burlington, MA: Elsevier Academic Press, 2005.

15. Harvey ML, Dadour IR, Gaudieri S. Mitochondrial DNA cytochrome oxidase I gene: potential for distinction between immature stages of some forensically important fly species (Diptera) in western Australia. Forensic Sci Int 2003;131(2-3):134-9.

16. Harvey ML, Mansell MW, Villet MH, Dadour IR. Molecular identification of some forensically important blowflies of southern Africa and Australia. Med Vet Entomol 2003;17(4):363-9. 
17. Tamura K, Dudley J, Nei M, Kumar S. MEGA4: Molecular Evolutionary Genetics Analysis (MEGA) software version 4.0. Mol Biol Evol 2007;24(8):1596-9.

18. Fan Z. Key to the common flies of China, 2nd ed. China: Science Press, 1992.

19. Rognes K. Blowflies (Diptera, Calliphoridae) of Fennoscandia and Denmark. Leiden: E.J. Brill, 1991.

20. Whitworth T. Keys to the genera and species of blow flies (Diptera: Calliphoridae) of America North of Mexico. Proc Entomol Soc Wash 2006;108(3):689-725.

21. Wells JD, Introna F. Jr, Di Vella G, Campobasso CP, Hayes J, Sperling FA. Human and insect mitochondrial DNA analysis from maggots. J Forensic Sci 2001;46(3):685-7.

22. Stevens JR, Wall R, Wells JD. Paraphyly in Hawaiian hybrid blowfly populations and the evolutionary history of anthropophilic species. Insect Mol Biol 2002;11(2):141-8.
23. Wallman JF, Leys R, Hogendoorn K. Molecular systematics of Australian carrion-breeding blowflies (Diptera: Calliphoridae) based on mitochondrial DNA. Invertebr Syst 2005;19(1):1-15.

24. Wells JD, Sperling FA. DNA-based identification of forensically important Chrysomyinae (Diptera: Calliphoridae). Forensic Sci Int 2001; 120(1-2):110-5.

Additional information and reprint requests:

Juck-Joon Hwang, Ph.D., M.D.

Department of Legal Medicine

College of Medicine

Korea University

126-1 Anamdong 5 ga

Seongbukgu, Seoul

Korea

E-mail: kuforen@gmail.com 